\title{
DRUG RECEPTORS AND THEIR EFFECTORS
}


Previously published volumes

1970 Aldridge: Mechanisms of Toxicity

1971 Rabin and Freedman: Effects of Drugs on Cellular Control Mechanisms

1972 Rang: Drug Receptors

1973 Callingham: Drugs and Transport Processes

1974 Parsons: Peptide Hormones

1975 Grahame-Smith: Drug Interactions

1976 Roberts: Drug Action at the Molecular Level

1977 Hughes; Centrally Acting Peptides

1978 Turk and Parker: Drugs and Immune Responsiveness

1980 Sandler: Enzyme Inhibitors as Drugs 


\section{BIOLOGICAL COUNCIL \\ The Co-ordinating Committee for Symposia on Drug Action}

\section{DRUG RECEPTORS \\ AND THEIR EFFECTORS}

Edited by

NIGEL J. M. BIRDSALL

National Institute for Medical Research, Mill Hill, London

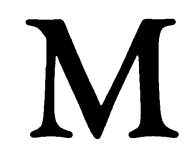


() Institute of Biology Endowment Trust Fund 1981

Softcover reprint of the hardcover 1st edition 1981

All rights reserved. No part of this publication may be reproduced or transmitted, in any form or by any means, without permission

First published 1981 by

The Scientific and Medical Division

MACMILLAN PUBLISHERS LTD

London and Basingstoke

Companies and representatives throughout the world

ISBN 978-1-349-05557-9 ISBN 978-1-349-05555-5 (eBook)

DOI 10.1007/978-1-349-05555-5 
Biological Council Co-ordinating Committee for Symposia on Drug Action

Report of a symposium held on 31 March and 1 April 1980 in London at The Middlesex Hospital Medical School

Sponsored by:

The Biochemical Society

British Association for Psychopharmacology

British Biophysical Society

British Pharmacological Society

Society for Experimental Biology

The Nutrition Society

The Pharmaceutical Society of Great Britain

The Physiological Society

The Organising Committee is grateful for generous financial help from:

Abbott Laboratories Limited

Astra Pharmaceuticals Limited

Astra Läkemedel AB

Beecham Pharmaceuticals Research

Division

The Boots Company Limited

Fisons Limited

Glaxo (1972) Charity Trust

Imperial Chemical Industries Limited

Kabi AB

Dr Karl Thomae GmbH
Miles Laboratories Limited

Pfizer Limited

Reckitt and Coleman Limited

Roche Products Limited

Smith Kline and French Laboratories

Limited

E. R. Squibb and Sons Limited

The Upjohn Company

Warner-Lambert/Parke-Davis

The Wellcome Foundation

Winthrop Laboratories

Organised by a Committee consisting of:

N. J. M. Birdsall (Chairman and Hon. Secretary)

J. W. Black

S. R. Nahorski

J. A. Parsons

H. P. Rang 


\section{Symposium contributors}

J. Axelrod, Section on Pharmacology, Laboratory of Clinical Science, National Institute of Mental Health, Bethesda, Maryland 20205, USA

M. J. Berridge, ARC Unit of Invertebrate Chemistry and Physiology, Department of Zoology, University of Cambridge, Downing Street, Cambridge CB2 3EJ, UK

C. P. Berrie, Division of Molecular Pharmacology, National Institute for Medical Research, Mill Hill, London NW7 1AA, UK

N. J. M. Birdsall, Division of Molecular Pharmacology, National Institute for Medical Research, Mill Hill, London NW7 1 AA, UK

A. J. Blume, Department of Physiological Chemistry and Pharmacology, Roche Institute of Molecular Biology, Nutley, New Jersey 07110 , USA

P. Boyd-Leinen, Department of Cell Biology, Section of Biochemistry, Mayo Medical School, Mayo Clinic, Rochester, Minnesota 55901, USA

A.S.V. Burgen, Division of Molecular Pharmacology, National Institute for Medical Research, Mill Hill, London NW7 1 AA, UK

D. Colquhoun, Department of Pharmacology, University College London, Gower Street, London WC1 E 6BT, UK

S. Eimerl, Department of Biological Chemistry, The Hebrew University of Jerusalem, Jerusalem, Israel

B. F. Erlanger, Department of Microbiology, Columbia University Cancer Center/Institute of Cancer Research, New York, New York 10032, USA
D. M. Fambrough, Department of Embryology, Carnegie Institution of Washington, 115 West University Parkway, Baltimore, Maryland 21210 , USA

W. Fischli, Department of Molecular Biology and Biophysics, Swiss Federal Institute of Technology (ETH), $\mathrm{CH}-8093$ Zürich, Switzerland

B. Gysin, Department of Molecular Biology and Biophysics, Swiss Federal Institute of Technology (ETH), CH-8093 Zürich, Switzerland

F. Hirata, Section on Pharmacology, Laboratory of Clinical Science, National Institute of Mental Health, Bethesda, Maryland 20205, USA

E. C. Hulme, Division of Molecular Pharmacology, National Institute for Medical Research, Mill Hill, London NW7 1 AA, UK

R. Jürss, Department of Biochemistry, Imperial College of Science and Technology, London SW7, UK

O. L. Kon, Department of Cell Biology, Section of Biochemistry, Mayo Medical School, Mayo Clinic, Rochester, Minnesota 55901, USA

M. Korner, Department of Biological Chemistry, The Hebrew University of Jerusalem, Jerusalem, Israel

M. E. Krouse, Division of Biology, California Institute of Technology, Pasadena, California 91125 , USA

R. Laugier, Unite 31, Institut National de la Santé et de la Recherche Médicale, 46 Chemin de la Gaye, 13009 Marseille, France 
H. A. Lester, Division of Biology, California Institute of Technology, Pasadena, California 91125 , USA

A. Maelicke, Max-Plank-Institut, Rheinlanddamm 201, D-4600 Dortmund, German Federal Republic

G. Martin-Dani, Graduate School of Medicine, Mayo Clinic, Rochester, Minnesota 55901, USA

J. M. Nerbonne, Division of Biology, California Institute of Technology, Pasadena, California 91125 , USA

G. Neufeld, Department of Biological Chemistry, The Hebrew University of Jerusalem, Jerusalem, Israel

A. Nishiyama, The Second Department of Physiology, Yamagata University School of Medicine, Zao, Yamagata 990-23, Japan

A. Noma, National Institute of Physiological Sciences, 444 Okazaki, Japan

W. Osterrieder, II. Physiologisches Institut der Universität des Saarlandes, 6650 Homburg/Saar, German Federal Republic

O. H. Petersen, Department of Physiology, The University, Dundee DD1 4HN, Scotland

H. G. Philpott, Department of Physiology, The University, Dundee DD1 4HN, Scotland
H. Prinz, Max-Planck-Institut, Rheinlanddamm 201, D-4600 Dortmund, German Federal Republic

D. F. Sargent, Department of Molecular Biology and Biophysics, Swiss Federal Institute of Technology (ETH), $\mathrm{CH}-8093$ Zürich, Switzerland

P. Schoch, Department of Molecular Biology and Biophysics, Swiss Federal Institute of Technology (ETH), $\mathrm{CH}-8093$ Zürich, Switzerland

M. Schramm, Department of Biological Chemistry, The Hebrew University of Jerusalem, Jerusalem, Israel

R. Schwyzer, Department of Molecular Biology and Biophysics, Swiss Federal Institute of Technology (ETH), Zürich, Switzerland

T. C. Spelsberg, Department of Cell Biology, Section of Biochemistry, Mayo Medical School, Mayo Clinic, Rochester, Minnesota 55901, USA

W. Trautwein, II. Physiologisches Institut der Universität des Saarlandes, 6650 Homburg/Saar, German Federal Republic

N. H. Wassermann, Department of Microbiology, Columbia University Cancer Center/Institute of Cancer Research, New York, New York 10032, USA 


\section{Contents}

\section{Sponsoring societies}

Bodies from whom financial support was received

Symposium contributors

$\mathrm{v}$

$\mathbf{v}$

vii

1. Introduction. N. J. M. Birdsall

2. Potassium Channels and the Muscarinic Receptor in the Sino-atrial Node of the Heart. W. Trautwein, W. Osterrieder and A. Noma

3. Interactions of Muscarinic Receptors with Guanine Nucleotides and Adenylate Cyclase. E. C. Hulme, C. P. Berrie, N. J. M. Birdsall and A. S. V. Burgen

4. NG108-15 Opiate Receptors: Characterisation as Binding Sites and Regulators of Adenylate Cyclase. A. J. Blume

5. Phospholipid Methylation and Receptor-mediated Transmission of Biological Signals through Membranes. J. Axelrod and F. Hirata

6. Implantation of Hormone Receptors: Fusion of Membrane Components with Cell Membranes. G. Neufeld, M. Korner, S. Eimerl and M. Schramm

7. Hormonal Control of Ion Permeability of the Pancreatic Acinar Cell Membrane Mediated by Intracellular Calcium. O. H. Petersen, A.

Nishiyama, R. Laugier and H. G. Philpott

8. Phosphatidylinositol Metabolism and Calcium Gating in a 5-HT Receptor System. M. J. Berridge

9. Interaction of Fluorescent Analogues of Acetylcholine with Nicotinic Acetylcholine Receptors and Acetylcholine Esterase. H. Prinz, R. Jürss and A. Maelicke

10. Light-activated Compounds as Probes for Nicotinic Acetylcholine Receptors. H. A. Lester, M. E. Krouse, J. M. Nerbonne, N. H. Wassermann and B. F. Erlanger

11. The Kinetics of Conductance Changes at Nicotinic Receptors of the Muscle End-plate and of Ganglia. D. Colquhoun

12. Adrenocorticotrophin-(1-24)-tetrakosipeptide Spans Lipid Membranes: Experiments with Liposomes. R. Schwyzer, W. Fischli, B. Gysin, D. F. Sargent and P. Schoch

13. Novel Regulations in Steroid Action: Role of Receptor Subunits and Chromosomal Proteins in Nuclear Binding. T. C. Spelsberg, P. Boyd-Leinen, G. Martin-Dani and O. L. Kon

14. Biosynthesis and Turnover of Nicotinic Acetylcholine Receptors.

D. M. Fambrough

The summing up. Sir Arnold Burgen $\quad 165$

Author index 166

$\begin{array}{lr}\text { Subject index } & 177\end{array}$ 